\title{
Preface: Perspectives on progress in ornitholimnology
}

\author{
Francisco A. Comín • Stuart H. Hurlbert
}

Published online: 31 May 2012

(C) Springer Science+Business Media B.V. 2012

\begin{abstract}
An introduction to papers presented in this volume is given describing the topics of interest dealt with in this special issue in the context of past and recent articles published on aquatic birds and limnology. Lack of holistic approach is observed in this review, while it is observed that most studies deal with community ecology, environmental factors regulating bird population distribution through space and time, and their management. However, the holistic approach taking into account interactions between different trophic levels and human regulations, and further studies relating ornitholimnology to global changes are not well enough represented in the literature.
\end{abstract}

Keywords Topics $\cdot$ Limnology $\cdot$ Aquatic $\cdot$ Birds · Ecosystem

Guest editors: F. A. Comín \& S. H. Hurlbert / Limnology and Aquatic Birds: Monitoring, Modelling and Management

F. A. Comín ( $₫)$

Instituto Pirenaico Ecología-CSIC, Av. Montañana 1005, 50192 Zaragoza-Jaca, Aragón, Spain

e-mail: comin@ipe.csic.es

\section{S. H. Hurlbert}

Department of Biology, San Diego State University,

San Diego, CA, USA

e-mail: shurlbert@sunstroke.sdsu.edu

\section{Introduction}

Science advances through different approaches involving the formulating and testing of theories proposed on the basis of observations. With respect to understanding of ecosystems, field observations are critical for solid advance. Following the development of new technologies for observations at large spatial scales, much ecosystem research has focused on effects of global changes. These include changes in land use, in climate change, and in other factors that regulate ecological processes and biodiversity around the world. A rich combination of different approaches is required to understand both old observations and the new phenomena generated by global change.

These generalities apply to the study of aquatic birds and their interactions with other components of aquatic ecosystems and, at the same time, often both generate and fulfill social demands for the benefits provided by birds to humans. Since the essay by Hutchinson (1951) that merely mentioned the potential similarity of birds and lacustrine copepods with respect to the relative size differences that permitted coexistence of species, and the early experiment by Hurlbert \& Chang (1983), which suggested the strong effects that aquatic birds might sometimes be expected to have on lake ecosystems, most ecological studies of aquatic birds have not been strongly ecosystem oriented. They have tended to focus on interactions between or among different bird species, with other studies on impacts of climate change (Wrona et al., 2006), on birds as vectors for 
viruses (Webster et al., 2007) and as indicators of pollution (Abdennadher et al., 2011). Ornitholimnology remains a frontier between two classic subject matters of ecology. Despite the increased number of studies dedicated to this issue over the past decades, full integration of the ecology of aquatic birds with the ecology of lakes and rivers is far away.

A search of the Web of Knowledge (WoK) in late December 2011 using the terms "aquatic" and "bird" and "ecology" found 2,000 articles published during the period 1960-2011. Only 120 publications were found during 1960-1980, and since 1980 there has been roughly a five fold increase in the number of such articles published per year (Fig. 1). Although many publications on aquatic bird ecology are not listed in this search, the trend does document the increased interest in ornitholimnology over the past decades.

Several classic topics have retained their interest for researchers during this period. They include interactions between birds and other groups of organisms living in aquatic ecosystems (macrophytes, macroinvertebrates, mammals, reptiles, and fishes), the trophic and foraging characteristics of aquatic birds, competition between aquatic birds for the territory and food, community structure, habitat-use characteristics and ecosystem management. The experimental approach to study interactions of birds with other groups of organisms (e.g., field experiments excluding birds from sites) remains little utilized, probably because of the logistic difficulties of establishing exclusion plots or areas on a reasonable scale.

Another set of articles are those relating to bird population dynamics and ecophysiological status. These often present bird census data or analysis of

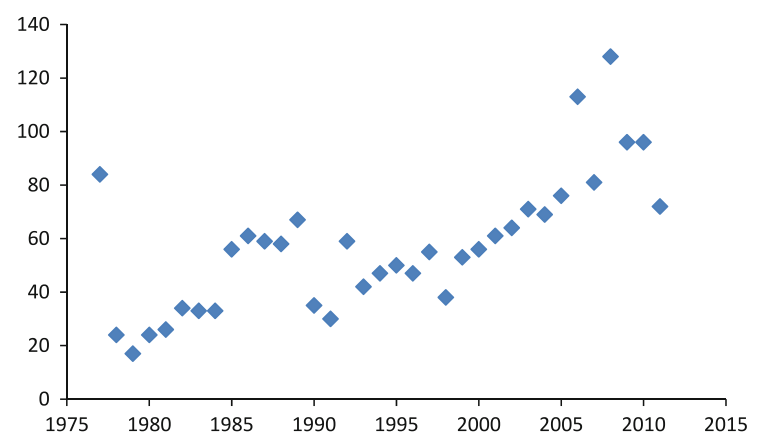

Fig. 1 Variation of the number of articles obtained from the Web of Knowledge/All Data Bases after a search of the terms "aquatic" and "bird" and "ecology" (http://apps.webofknow ledge.com on 05/Jan./2012) the effects of pollutants and parasites on birds. Systematic censuses and less regular counts of bird populations done all around the world by both amateurs and professionals provide important databases. However, these type of studies often are published online or in specialized journals not fully covered by the WoK. They were not well represented in our search. For example, missing were the many studies on the effects of botulism and saturnism on birds. The relatively recent boom of studies on birds as transporters of influenza A virus was reflected in the search results, as was the renewed interest in biodiversity topics over the last decade.

Investigations on the role of aquatic birds in the functioning of aquatic ecosystems are still much needed, just as are the investigations of how the population dynamics of aquatic birds are dependent on availability and properties of aquatic ecosystems, especially as they are being modified by man. Studies with an holistic approach to ecosystems, such as those by Reed \& Moisan (1971), Harper (1984), and Borcard et al. (1992), and studies using the experimental approach to assess the role of birds on aquatic ecosystems and their ecological relationships, such as Steinmetz et al. (2003), can be good models for future research.

The articles in this special issue are derived from the 6th Symposium on Limnology and Aquatic Birds (held at Huesca, Spain, in 2009). This series of symposia is endorsed by the International Society of Limnology and was initiated by J. Kerekes and the SIL Working Group on Limnology and Aquatic Birds (Kerekes \& Pollard, 1994; Faragó \& Kerekes, 1997; Comín et al., 2000; Musil \& Albrecht, 2000; Hanson \& Kerekes, 2006; Andrikovics et al., 2008). It was not possible to include all of the articles from the symposium in this issue, and some of the articles presented here are by authors who could not attend the symposium. Athearn et al. (2012, this issue) present results on the interannual variability of aquatic bird populations in the salt ponds of San Francisco Bay and offer guidelines for wise management of this ecosystem with focus on bird conservation. Pescador et al. (2012, this issue) used multi-year censuses on Patagonian lakes to discern the effects on different species of aquatic birds of lake size and the presence of mink. Fox and Walsh (2012, this issue) and Fox et al. (2012, this issue) present detailed information on environment-related migratory dynamics of the White-fronted Geese (Anser albifrons 
flavirostris). Jehl et al. (2012, this issue) describe the mortality effects of high sodium carbonate levels in soda ash evaporation ponds on the Eared Grebe (Podiceps nigricollis). Faragó \& Hangya (2012, this issue) use an 8-year data set to document how water level fluctuations of the Danube affect abundances of aquatic birds. Matuszak et al. (2012, this issue) used exclosure experiments and discovered that at Lower Lake Constance Eurasian Coots (Fulica atra) reduce macrophyte biomass by more than $40 \%$. Using similar methods, Smith et al. (2012, this issue) found a similar reduction of sedge biomass by Black Swans (Cygnus atratus) in an Australian wetland. Horváth et al. (2012, this issue) intensively monitored invertebrate populations and water birds on a reconstructed Hungarian wetland, finding interesting correlations between the two groups. Similarly Väänänen et al. (2012, this issue) found for 28 Finnish lakes correlations between abundances of certain ducks and certain fish species that compete with them for food. Newbrey et al. (2012, this issue) used stable isotope analysis to establish not only dietary differences between two grebe species on a large Alberta (Canada) lake but also differences in the portions of the lake used. Bucher \& Curto (2012, this issue) document the influence of climate change on lake size and flamingo abundance at South America's largest salt lake, Mar Chiquita. Ecosystem management issues are dealt with by Huang \& Isobe (2012, this issue), who address one of the key questions of ornitholimnology namely that of the carrying capacity of aquatic ecosystems for bird populations.

Acknowledgments Editing and publishing these articles have been possible with the help of a group of persons who kindly reviewed the manuscripts: D. Anderson, D. Barnum, A. Bechet, S. Boyd, E. Bucher, T.W. Custer, J. Eadie, J. Fjeldsa, A.D. Fox, E. Garcia-Berthou, A. Grant, A.G. Gordus, G. Gunnarson, D. Herbst, H.J. Homan, J. Jehl, J. Kerekes, D.T. King, J. Kushlan, T. Lauridsen, D. Moreno, N.D. Niemuth, B. Obrador, P. Musil, M.T. O'Hare, C. Pedrocchi, F. Robledano, H. Rodriguez-Perez, I. Sammalkorpi, M. Sanchez, H. Sandsten, A. Studer-Thiersch, J. Takekawa, and B. Tonn. Special thanks are due to Stuart Halse, Associate Editor for this volume, whose dedicated interest to the publication of these articles has been very helpful.

\section{References}

Abdennadher, A., F. Ramirez, R. M. Salah, X. Ruiz, L. Jover \& C. Sanpera, 2011. Little Egret (Egretta garzetta) as a bioindicator of trace element pollution in Tunisian aquatic ecosystems. Environ Monit Assess 175: 677-684.
Andrikovics, S., L. Forró \& J. Kerekes (eds), 2008. Limnology and aquatic birds 2006, Eger, Hungary. Acta Zoologica Academiae Hungaricae 54.

Athearn, N. D., J. Y. Takekawa, J. D. Bluso-Demers, J. M. Shinn, L. A. Brand, C. W. Robinson-Nilsen \& C. M. Strong, 2012. Variability in habitat value of commercial salt production ponds: implications for waterbird management and tidal marsh restoration planning. Hydrobiologia (this issue). doi:10.1007/s10750-012-1177-y.

Borcard, D., P. Legendre \& P. Drapeau, 1992. Partialling out the spatial component of ecological variation. Ecology 73 : 1045-1055.

Bucher, E. H. \& E. Curto, 2012. Influence of long-term climatic changes on breeding of the Chilean flamingo in Mar Chiquita, Córdoba, Argentina. Hydrobiologia (this issue). doi:10.1007/s10750-012-1176-z.

Comín, F., J. A. Herrera \& J. Ramirez-Ramirez (eds), 2000. Limnology and Aquatic Birds: Monitoring, Modelling and Management. Universidad Autonoma de Yucatan, Merida.

Faragó, S. \& J. Kerekes (eds), 1997. Limnology and Waterfowl: Monitoring, Modelling and Management. Wetlands International Publication 43 \& Hungarian Waterfowl Publication 3 .

Faragó, S. \& K. Hangya, 2012. Effects of water level on waterbird abundance and diversity along the middle section of the Danube River. Hydrobiologia (this issue). doi:10.1007/s10750-012-1166-1.

Fox, A. D. \& A. J. Walsh, 2012. Warming winter effects, fat store accumulation and timing of spring departure of Greenland White-fronted Geese Anser albifrons flavirostris from their winter quarters. Hydrobiologia (this issue). doi:10.1007/s10750-012-1173-2.

Fox, A. D., H. Boyd, A. J. Walsh, D. A. Stroud, J. Nyeland \& R. Cromie, 2012. Earlier spring staging in Iceland amongst Greenland White-fronted Geese Anser albifrons flavirostris achieved without cost to refuelling rates. Hydrobiologia (this issue). doi:10.1007/s10750-012-1174-1.

Hanson, A. \& J. Kerekes (eds), 2006. Limnology and waterbirds. Hydrobiologia 567.

Harper, D., 1984. Recent changes in the ecology of Lake Naivasha, Kenya. Verhandlungen Internationale Vereinigung Limnology 22: 1193-1197.

Horváth, Z., M. Ferenczi, A. Móra, C. F. Vad, A. Ambrus, L. Forró, G. Szövényi \& S. Andrikovics, 2012. Invertebrate food sources for waterbirds provided by the reconstructed wetland of Nyirkai-Hany, northwestern Hungary. Hydrobiologia (this issue). doi:10.1007/s10750-012-1170-5.

Huang, G. \& M. Isobe, 2012. Carrying capacity of wetlands for massive migratory waterfowl. Hydrobiologia (this issue). doi:10.1007/s10750-012-1165-2.

Hutchinson, G. E., 1951. Copepodology for the onithologist. Ecology 32: 571-577.

Hurlbert, S. H. \& C. C. Y. Chang, 1983. Ornitholimnology: effects of grazing by the Andean flamingo (Phoenicoparrus andinus). Proceedings of the National Academy of Sciences of the United States of America 80: 4766-4769.

Jehl, J. R., A. E. Henry \& J. St. Ledger, 2012. Waterbird mortality in hypersaline environments: the Wyoming trona ponds. Hydrobiologia (this issue). doi:10.1007/s10750012-1167-0. 
Kerekes, J. J. \& B. Pollard (eds), 1994. Aquatic birds in the trophic web of lakes. Hydrobiologia 279/280 (Developments in Hydrobiology 96: 524).

Musil, P. J. \& T. Albrecht, 2000. Abstracts and selected papers of the third Conference of Aquatic Birds Working Group of Societas Internationalis Limnologiae (SIL). Sylvia 36, Suppl. Limnologiae 68.

Matuszak, A., M. Mörtl, P. Quillfeldt \& H.-G. Bauer, 2012. Exclosure study on the exploitation of macrophytes by summering and moulting waterbirds at Lower Lake Constance. Hydrobiologia (this issue). doi:10.1007/s10750012-1168-z.

Newbrey, J. L., C. A. Paszkowski \& B. A. Gingras, 2012. Trophic relationships of two species of grebe on a prairie lake based on stable isotope analysis. Hydrobiologia (this issue). doi:10.1007/s10750-012-1171-4.

Pescador, M., S. Díaz \& S. Peris, 2012. Abundances of waterbird species on lakes in Argentine Patagonia as a function of season, lake size and presence of mink. Hydrobiologia (this issue). doi:10.1007/s10750-012-1175-0.

Reed, A. \& G. Moisan, 1971. The Spartina tidal marshes of the St. Lawrence estuary and their importance to aquatic birds. Naturaliste Canadien 98: 905-922.
Smith, A. N., K. A. Vernes \& H. A. Ford, 2012. Grazing effects of Black Swans Cygnus atratus (Latham) on a seasonallyflooded coastal wetland of eastern Australia. Hydrobiologia (this issue). doi:10.1007/s10750-012-1169-y.

Steinmetz, J., S. L. Kohler \& D. A. Soluk, 2003. Birds are overlooked top predators in aquatic food webs. Ecology 84 : 1324-1328.

Väänänen, V. M., P. Nummi, H. Pöysä, M. Rask \& K. Nyberg, 2012. Fish-duck interactions in boreal lakes in Finland as reflected by abundance correlations. Hydrobiologia (this issue). doi:10.1007/s10750-012-1172-3.

Webster, R. G., K. Scott, D. Hulse, et al., 2007. Evolution of influenza a viruses in wild birds. Journal of Wildlife Diseases 43: S1-S6.

Wrona, F. J., T. D. Prowse, J. D. Reist, J. E. Hobbie, L. M. J. Lévesque \& W. F. Vincent, 2006. Climate change effects on aquatic biota, ecosystem structure and function. Ambio 35: 359-369. 